\title{
China's Economic Transformation and Industrial Upgrading Under the New Normal
}

\author{
Zhan Gao
}

\author{
Macau University of Science and Technology, Macau,999078, China \\ *Corresponding author Email: 2459462407@qq.com
}

\begin{abstract}
after entering the new normal, China's economy needs to be properly transformed and developed. Based on the background of the new normal, this paper discusses the transformation and industrial upgrading of China's economy, and explains the necessity and methods of industrial upgrading.
\end{abstract}

Keywords: new normal, economic transformation, industrial upgrading

\section{INTRODUCTION}

Over the past 30 years, the average annual growth rate of China's economy has reached $9.7 \%$, and its growth rate is faster than that of major developed countries, making it the world's second largest economy. However, due to its large population base, my country's per capita GDP ranks 80th in the world. Today, China's economic growth rate will drop to $6 \%-7 \%$. Although this is still a relatively fast economic growth rate globally, compared with the previous growth rate of the poor, the Chinese economy will enter a medium-to-high-speed growth rate. Stage, entering the "new normal" of economic growth. After 40 years of rapid economic development in China, it has now entered a transitional period of economic development, from the original short-term fluctuating economic development state to a stable new development state, rather than showing a short-term unstable state.

\section{UNDER THE "NEW NORMAL" CHINA'S TRADITIONAL ECONOMIC DEVELOPMENT MODEL NEEDS TO BE TRANSFORMED AND UPGRADED}

\subsection{The necessity of industrial upgrading}

After the reform and opening up, China's economic system has been reformed from a planned economy to a market economy, and a market economy power system has been established. At the same time, the market economy operation model and related rules and regulations have been improved, which has improved economic efficiency at the time and promoted China's economic system. Perfection and development. In addition, my country has a huge market development space, which provides impetus for the development of a new economic system. Over the past four decades, the huge engine of economic growth has been mainly driven by the factors that rely on cheap labor, land elements, large amounts of resource development and damage to the environment and ecology to build a large-scale investment-driven and project-driven economic engine[1]. In addition to these factors, the government also plays an important role. Local governments at all levels regard the improvement of local people's livelihood and economy as their top priority. In this process, their "visible hands" and "invisible hands" play an important role in promoting The rapid development of China's economy.

In view of such a rapid development speed, in the long run, it is an inevitable trend that China's economic development will be hindered, which is also an important reason for the necessity of economic transformation. Due to the continuous development of China's economy and the continuous deepening of reform and opening up, it has gone from a shortage in the early stage of reform to a surplus now. This is the main cause of economic transformation. Non-human factors can be controlled at will, but it is necessary for economic development to a certain stage. The situation facing. Therefore, we can understand the current problems facing China's economic development and the necessity of industrial upgrading from the following six aspects: First, if only measured by the increase in quantity and the continuous expansion of scale, serious negative effects may occur. ; Second, as supply costs continue to rise, labor has developed from surplus to shortage; third, the environment has been destroyed, and 
the road of pollution first, then governance; fourth, the world economic depression, the deterioration of the international economic environment, and China's economic development Extremely unfavorable; Fifth, China's economic development has entered a stage of demand transformation, and the original normal development has encountered obstacles. With the increase in the income level of the country and the people, the changes in the demand structure will lead the Chinese economy to enter a new level and enter a new normal; sixth, the arrival of the information technology revolution, along with the globalization of information technology, China is also facing greater Opportunities and challenges of the world, usher in a new stage of economic development. This is the objective law of economic development and cannot be changed by human will.

\subsection{China's low competitiveness}

China's low-end position in the value chain of global trade has prompted China's economic transformation and upgrading. Although my country's overall economic strength is very strong, and it is the second largest economy in the world, especially in the secondary industry, my country is still at the middle and low end of the value chain. Among important industrial products, China ranks first in the world in output of nearly 300 products. China's automobile production. China's machine tool production accounts for the world's total production. Shipbuilding and power generation equipment are the world's largest. The number of garment exports in the light industry is staggering. From the perspective of output alone, China's economic scale is indeed very large. The crux of the problem lies in "big but not strong", lack of core technology, and export products are basically labor-intensive products. Many high-tech. High value-added products need to be maintained by imports. For example, in the Chinese automobile industry, the main body of Chinese automobiles in the market is Sino-foreign joint venture brands, and the key technology is in foreign companies. However, China only completes simple manufacturing and assembly, so all profits are $80 \%$ is owned by foreign companies, and only $20 \%$ is left in our hands. In the global trade industry chain, China Yuan's position is very sad;

Another example is China's production of ordinary machine tools in the world, but cannot produce high-end CNC machine tools and so on. Due to the continuous increase in labor costs in China in recent years, some of China's traditional manufacturing industries have moved to the central and western regions and Southeast Asia where labor costs are lower, and the proportion of China's labor-intensive product exports has been declining. This traditional development of low cost and low prices as a global competitiveness The model cannot last too long. Only transformation and upgrading can help China achieve healthy economic development. The transformation and development of the industry cannot be separated from technological innovation[2]. Judging from the table, manufactured goods. The proportion of export trade interest is still large, the proportion of primary products is small and has declined, and the proportion of high-tech products exports still needs to be increased.

\subsection{The overcapacity caused by China's investment in the economy has made China's economy unsustainable.}

In the past 30 years, China has also relied on investment to drive economic development. Statistics show that China's investment rate is $10 \%$ to $20 \%$ higher than the world's average investment rate. Investment has a dual effect. When investing, it will create social demand and economic growth at the same time. However, after the investment is over, it will also form a certain Supply capacity. According to this theory, it can be speculated that when a country or region has a large amount of investment, it will have a strong pulling effect on the economy, but at the same time it will produce a large amount of supply. At this time, if consumption cannot be increased accordingly, excess capacity cannot be avoided. The phenomenon of overcapacity in China's steel industry and coal industry is caused by this. This situation requires us to want to resolve excess capacity. Sustainable development depends on the effective use of resources. Obviously, the failure to effectively solve the problem of overcapacity in China will directly affect the sustainable development of the Chinese economy.

\subsection{Rising prices of production factors and changes in comparative advantages are forcing China to transform and upgrade}

The rise in the cost of production factors and the decline in supply efficiency have inhibited the development of the manufacturing industry, especially the restrictions on labor-intensive industries. In the past few decades after the reform and development, China's rapid economic growth has depended on the continuous increase in labor and capital investment and the continuous progress of science and technology, but now the supply efficiency of these three factors is declining. From the perspective of labor input, our country "gets old before the rich." China is now the only country in the world with an aging population of more than 100 million, with an elderly population accounting for $10 \%$. At present, my country has seen a decline in the employment participation rate; labor wages are growing faster than GDP growth. The rise in labor costs will inevitably lead to a continuous decline in industrial competitiveness. The decline in exports now fully shows 
that the low price advantage created by cheap labor in the past no longer exists, and the old commodity export model no longer adapts to China's national conditions. In terms of capital investment, my country's investment in fixed assets fell to $16.1 \%$ in the first three quarters of 2015 , the rate of capital formation caused by the growth rate of investment also slowly declined, and technological progress was also slow.

\subsection{Domestic problems and contradictions are becoming increasingly prominent, and land problems and environmental pollution problems need to be resolved urgently}

In terms of real estate issues, the land supply system is the most fundamental reason for China's high housing prices. According to the research conducted by the China Land Policy Reform Task Force (2006), after the tax-sharing system reform in 1994, land transfer fees accounted for a very large proportion of local fiscal revenues. In 2014, China's land transfer fees accounted for $54.01 \%$ of local fiscal revenues, which is more than that. It eased in 2013, but the proportion is still high. In addition, real estate investment still accounts for a high proportion of GDP. The current market mechanism for land compensation is not sound enough. Some local governments obtain a large amount of land income by demolishing rural houses and changing land use types to attract investment and stimulate economic development. Due to the lack of a standardized system, relocation has led to mass incidents and vicious incidents. Frequently. China's traditional development model is based on high input and high output, and the resource utilization rate is very low, which brings a lot of energy demand and social environmental problems. In 2014, China accounted for $23 \%$ of global energy consumption and is the world's largest energy consumer and energy production park.

\subsection{Demographic changes}

China's large amount of cheap labor is an important factor in attracting foreign investment. China has also gradually promoted economic development and enhanced China's international status by relying on Chinese manufacturing. However, the change in the population structure indicates that China's economic situation cannot be sustained.

From 1995 to 2014, the population aged 65 and over continued to increase in China, and the old-age dependency ratio increased, reaching $13.7 \%$ in 2014, and the child dependency ratio has a downward trend. Generally, a country with a population of 60 years and over reaching $10 \%$ or a country with 65 years of age and over reaching $7 \%$ or more indicates that the country has entered the aging stage. In 2014, the ratio of China's population aged 65 and over to the total population at the end of the year was $10.06 \%$, which indicates that China has entered the aging stage.

According to the performance of the national economy released by the National Bureau of Statistics, in 2014 , the working-age population between the ages of 16 and 60 decreased by 3.71 million from the end of the previous year. This is the third consecutive year that the absolute number of the working-age population in China has fallen. The growth of urban employed population is also narrowing. In 2014, urban employed persons increased by 10.7 million over the end of the previous year, which was significantly lower than 11.38 million in 2013 and 11.88 million in 2012. Although my country has fully liberalized the second-child policy in 2015 , it will not be immediate.

Demographic changes and the emergence of the "Lewis Turning Point" have led to the disappearance of the "demographic dividend" and the disappearance of the comparative advantage of low-cost labor. Under the impact of the international environment, relying on external demand to drive economic growth is unsustainable, and relying on economic transformation to solve the adverse impact of labor reduction It is a feasible solution.

\section{THE SOURCE OF ECONOMIC DEVELOPMENT POWER UNDER THE NEW NORMAL}

Combining various factors, the author believes that the driving force of China's economic development under the new normal is mainly the market competition pressure, the development drive of innovation factors and the further deepening of reform and opening up. The following three main reasons will be discussed one by one.

\subsection{Market competition pressure}

When the original normal economic development comes to an end, a corresponding surplus economy will be produced. These surplus economies compete for development. There will be progress in the process of competition. According to the trend of survival of the fittest, China's economic system can be re-developed and planned. China has become the new dominant force, and economic transformation and upgrading have been developed.

\subsection{Development drive of innovation factors}

In the face of new market demands, innovation is the foundation for survival. Only by keeping up with the trend of innovation can companies turn them into opportunities, consolidate their original foundations, develop new fields, and transform from the original "quantity" to "quality". Improving production quality, 
and personalized, high-quality, high-value innovations have become new growth points for economic development[3]. Innovation drive is not only reflected in product innovation, process innovation, improvement of equipment level, and raw material innovation driven by meeting new demands, but also in terms of business model innovation and market development approach innovation based on information network technology platforms.

\subsection{Further deepening of reform and opening up}

Reform and opening up is an important factor to release the market economy mechanism. The ultimate goal of state-owned economic reform is to break the state-owned economy market monopoly, create a new market economy mechanism, deal with long-standing inefficiencies, and optimize the property rights structure, innovate business models or Economic system, realizing the transformation of the state-owned economy, and releasing the potential of China's economic system. In addition, deepening the market economic system, standardizing market order, and optimizing the market environment require a high degree of cooperation from the government, which is also one of the driving forces for government development under the original economic state. In the state of the new normal, the government becomes the manipulator of the market economy system. The opportunity for the government to directly allocate resources only exists when the market is out of control, such as the infrastructure of public services. In addition, the government is one of the main bodies of economic interests, and its role will also undergo tremendous changes. The transformation of government functions under the new normal is a key link to deepen the reform and bring the market mechanism into play.

\section{THE BASIC STRATEGY OF CHINA'S ECONOMIC TRANSFORMATION AND UPGRADING}

At present, China's economic growth is slowing down, lack of motivation, rising production costs, and many internal and external environmental problems. How can China's economic development under the "new normal" transform and upgrade? According to China's national conditions, this article believes that China should start from the following Four aspects

With the help of the "Belt and Road" strategy, continue to deepen the reform and opening up policy, and promote reform through economic opening. This is also the most fundamental strategy. The most fundamental reason for China's rapid economic growth for more than 30 years is reform and opening up. The test of practice is in line with China's own actual situation, and the potential for economic growth through reform and opening up has been remarkable. To solve the problem of the driving force of sustained economic growth, we need to further implement reform and opening up. Since the Chinese government put forward the "One Belt One Road" strategy, Chinese enterprises' foreign investment cooperation has grown rapidly.

While obtaining new development opportunities for their own overseas investment and cooperation, Chinese enterprises also promote the economic prosperity and development of countries and regions with relatively backward industries. For Chinese companies, "going out" is a very important way. "Going global" is to help digest production capacity and eliminate backward and excess production capacity. Although a number of backward enterprises are destined to be eliminated with the development of the economy, it is necessary to pay attention to the employment problem. Employment is directly related to the development of my country's economy and the quality of life of the people.

Implementing innovation-driven strategies, promoting economic transformation and upgrading, and actively developing strategic emerging industries are the main lines of China's economic development under the new normal. "Innovation" is the first of the five development concepts, which shows its importance. The injection of new ideas, new ideas, and new technologies has allowed many traditional enterprises to find new development paths[4]. Traditional industries rely on technological innovation, through machine equipment and digital management, to upgrade the production line to increase product productivity while reducing production factor input, which can win more profits for enterprises, enhance their competitiveness, and bring new ideas to industrial transformation and upgrading. Opportunities. In June 2015, the National Development and Reform Commission launched seven policies to support strategic emerging industries, proposed to implement innovation-driven development strategies, and provided policy support for emerging industries in terms of technology, intellectual property rights, talents, taxation and finance. The rapid development of the Internet industry is a microcosm of emerging industries. The rapid rise of e-commerce in recent years is an innovation to the traditional marketing model. China's e-commerce market data report shows that from 2010 to 2015 , the volume of e-commerce transactions increased year by year, and indirectly led to more than 20 million jobs. The improvement of Internet infrastructure and the government's vigorous promotion have promoted the rapid development of e-commerce. The development of chain wholesale, logistics, retail and other industries. Implementing innovation-driven strategies and promoting economic transformation and upgrading are the mainstream of my country's economic development at this stage[5]. 
Give full play to the government's function and role in market regulation, adjust the direction of investment, and maximize its driving role in economic development. In the past, my country used government-led investment methods to directly make large-scale investments in profitable and competitive industries. This kind of wrong investment method confuses the boundary between the government and the market, and not only competes with the people for profit. The investment efficiency is low, but it is also easy to cause government officials to abuse their power to breed corruption. Entering the stage of the new economic normal, my country should comprehensively deepen the reform of resource allocation methods and increase resource utilization. While giving full play to the decisive role of the market, we should give full play to the government's regulatory and guiding role in the field of market failure: one is to increase investment in infrastructure; the other is to increase investment opportunities in high-tech product formats to maximize social marginal benefits; three It is the government that should eliminate investment barriers, expand the scope of investment and financing, and improve the management system. Although overcapacity is caused by investment, China's investment in infrastructure construction and the development of high-tech industries is far from sufficient. This requires the government to play a guiding role and change the old wrong investment methods as soon as possible, so that limited investment Come more economic benefits.

Encourage the development of environment-friendly and resource-saving industries, and form a new situation of harmonious development between man and nature. In the past, in order to promote economic development, China vigorously introduced foreign businessmen, while developed countries have long been aware of environmental protection and put high-pollution and low-tech industries in China. Although China's backward economic status has been improved to a certain extent, the environment is now polluted. The problem of waste of resources and resources has become more and more serious. In line with the "coordination, green and sharing" of the five development concepts mentioned by the General Secretary, China should strengthen corporate investigations in the process of introducing foreign investors, refuse to introduce high-consumption and high-polluting industries, and actively encourage them Domestic industries adopt emerging technologies for pollution control. my country should also actively adjust the industrial structure, reduce the industrial proportion of the heavy chemical industry and encourage the development of service industries and high-tech industries. Strictly control pollution sources and return the public a blue sky.

Both supply and demand exert force.In China's economic transformation under the new normal, the extensive growth model caused by the original simple demand-side management must be changed, and the supply-side structural reform should be strengthened while expanding aggregate demand. In the short-term, macro-control needs to achieve stable growth and expectations through demand-side management, and in the long-term, focus on improving quality and efficiency, promoting the steady and continuous improvement of total factor production rates, and further stimulating market vitality.

Supply-side structural reforms are the highlight and focus of economic transformation. It emphasizes de-capacity, de-inventory, deleveraging, cost reduction, and shortcomings. It strengthens high-quality supply from the production field, reduces ineffective supply, expands effective supply, improves the adaptability and flexibility of supply structure, improves total factor productivity, and makes supply system Better adapt to changes in demand structure[6].

Short-term and long-term joint reforms, demand and supply work together to stabilize economic growth, promote long-term development, release system dividends, build a new type of country, and allow China to converge from extraordinary growth to normal growth.

Innovation drives economic growth. Innovation is the internal driving force of economic growth. China's 30 -year rapid growth is factor-driven, and is the result of the emergence of productive entrepreneurial activities led by the use of knowledge and organizational and institutional changes. With the scarcity of resources, the emergence of the Lewis turning point, the reduction of the demographic dividend, and the reduction of the technological gap, factor-driven economic growth is unsustainable. It is now time to seize the opportunity of transformation, based on domestic factor endowments and comparative advantages, and complete the transition from factor-driven to innovation-driven. The economic transformation from production-based entrepreneurship to innovative entrepreneurship, and from knowledge utilization to knowledge creation, realizes an economic form dominated by knowledge creation.

The government changes its functions. The transformation of government functions can improve the operational efficiency of the administrative system, reduce social transaction costs, optimize the allocation of social resources, enhance the endogenous driving force of China's economic development, play the role of macro-control and market supervision, and shape the relationship between the new government and the market to achieve The transition from a controlled government to a service-oriented government.

On the one hand, the government should streamline administration and delegate power, with the market as the mainstay, and the government as a supplement to allow the market to develop freely and healthily; on the 
other hand, the government should adapt to and lead the new normal of economic development, take public service as its purpose, and assume government responsibilities. Furthermore, the government should make full use of the emerging field of "Internet + " to transform offline services into online operations, reduce human capital, and improve service efficiency.

Reform of state-owned enterprises. State-owned enterprises have three core properties: social, policy and strategic leadership. In the process of state-owned enterprise reform, firmly grasp these three core properties, clearly determine the position, accelerate the separation of government and enterprise, strengthen capital flow, better grasp the lifeline of the national economy, and achieve a smooth transition of the second economic transformation.

The reform of state-owned enterprises is not a simple transition from state-owned to privately-owned enterprises. Some areas must be controlled by the state and the government, such as military industry, national defense and other industries related to national security, public goods, low profitability enterprises and some emerging enterprises that require strong government support business[7]. It is possible to implement measures to separate the investment and operation of state-owned enterprises, and the separation of ownership and management rights, so as to stimulate the innovation momentum of state-owned enterprises and improve operational efficiency.

To sum up, under the new normal, China's economic transformation and upgrading should actively play the guiding role of the government, make timely policy guidance according to the current national conditions in China, and increase construction efforts in investment, industrial structure adjustment, innovative industry support, etc., so as to solve the problem. The problems in the process of China's economic transformation and upgrading have fundamentally improved industrial competitiveness, enhanced technological innovation capabilities, and enhanced industrial international competitiveness.

\section{CONCLUSION}

Under the new normal, China faces many challenges. The most important solution is to firm up the policy of economic transformation and implement the methods of industrial transformation. I think that in the supply-side structural reforms, adjusting the economic structure and promoting industrial upgrading, a large number of workers are facing unemployment[8]. How to provide them with livelihood security and promote their reemployment has become a major problem. Based on this, the author believes that, on the one hand, it is necessary to control the rate of increase of the unemployed, reduce production capacity through a reasonable process, and prevent large-scale unemployment from causing social unrest; on the other hand, implement the "three subsidies and one reduction" aid to stabilize jobs, and unemployment insurance According to the regulations, the fund will provide transfer training subsidies, job forest subsidies, and social insurance subsidies to enterprises that reduce overcapacity, so that enterprises will not lay off or reduce the number of layoffs[9]; furthermore, the reemployment of unemployed persons shall be included in the policy scope, free skills training shall be provided, entrepreneurship subsidies shall be provided, It reemployed spontaneously.

In terms of policy, our country must attach importance to education. Innovation comes from the accumulation of knowledge, and knowledge is obtained through education. In the process of the second economic transformation, innovation is the driving force to promote economic growth[10]. Without the accumulation of knowledge, it is unrealistic to guess innovation out of thin air. Therefore, we must pay attention to the training of professional skills and education. Furthermore, we must continue to accelerate the development of the tertiary industry. Before 2014, industry was the main driving force for economic growth, but in 2014, the tertiary industry surpassed the secondary industry to rank first. In 2015, half of the GDP was driven by the tertiary industry. The opening of the service industry market has become the highlight of market-oriented reforms, and the vigorous rise of the tertiary industry will guide the successful transformation of the economy.

\section{REFERENCES}

[1] Wang Yangyang, Wang Qianqian. Research on the transformation strategy of commercial circulation economy under the background of economic new normal [J]. Business economy research, 2020 (15): $25-27$

[2] Gao fan. Why China's economy has strong self-healing ability [J]. People's forum, 2020 (21): 12-16

[3] Zhao Shan. Digital economy has become a key force driving China's economic growth [n]. China economic times, 2020-07-21 (004)

[4] Cheng guangbin, Zhou Feng. New urbanization, upgrading of industrial structure and quality of China's economic growth $[\mathrm{J}]$. Journal of Shihezi University (PHILOSOPHY AND SOCIAL SCIENCES), 2020, 34 (03): 13-23

[5] Gu Dian, Xu Xiaojing. The impact of industrial structure optimization and upgrading on ecological efficiency in China [J]. Ecological economy, 2020,36 (06): 58-67 
[6] Yan Yan. Spatial and temporal evolution of China's urban economic transformation and its influencing factors [D]. Henan University of finance, economics and law, 2020

[7] Ren Li Na. China's economic transformation needs "new infrastructure" [J]. People's forum, 2020 (15): 184-185

[8] Zhang Xiaodong. Exploration of China's sea power in economic transformation: focusing on national strategic level $[\mathrm{J}]$. Asia Pacific security and ocean research, 2020 (01): 58-73+3

[9] Han Yuetong. Causes and suggestions for China's economic slowdown $[\mathrm{J}]$. Cooperative economy and technology, 2020 (01): 22-23

[10] Xu Weicheng, Zhou Tian. Internet technology progress and the optimization and upgrading of China's industrial structure: Theory and empirical study [J]. Industrial Economic Review (Shandong University), 2019,18 (04): 96-123 